\title{
Of Songs and Chants and Religious Rants: Late Sixteenth Century Hymns and Spiritual Songs Among Followers of Caspar von Schwenckfeld
}

E.J. FURCHA

By the middle of the sixteenth century, Christians were divided into tolerated and accepted groups, and those that were unacceptable within the established structures of the day. On the continent three categories were generally recognized: adherents of Rome, the Reformed (loosely identified with Zwingli and Calvin) and the Lutherans. In England the Church of England had taken shape, not without serious challenge.

Among those who were not tolerated were the so-called Anabaptists, anti-trinitarians, spiritualists and enthusiasts of varying degrees - looked upon as sectarians and schismatics and therefore not readily accepted by society at large as bona fide Christians. Though church historians of the period such as George $\mathrm{H}$. Williams have classified these heterodox groups and individuals, their respective theological tenets defy ready systematizing. To the extent that they expounded their ideas and belief structures in writing, they usually did not direct their tracts to scholars. As a result, they made few attempts at being consistent. Their normal intent was to nurture followers or would-be-followers through hortative discourses which often drew on and interpreted the Scriptures. On occasion, however, they simply stressed the "inner life", insisting that this was indeed the proper realm of the Spirit. None of these individuals or groups outside the mainstream of sixteenth century Christendom would adhere to an acknowledged magisterium. Hence, they shared no common theological system and had found no mechanism by which individuals could readily work together or through which their ideas might be disseminated.

The remarkable proliferation of printing presses, however, facilitated the production of hymnsheets and collections of spiritual songs. In a period of less than twenty-five years (c. 1524-1546), more than one hundred evangelical hymn collections were published in Germany alone. Though some of these were "authorized" by Martin Luther, many had no 


\section{0 / Renaissance and Reformation}

official ecclesiastical status. Their distribution depended on popular demand and on the skill of booksellers to sell heterodox religious material before censors would ban or confiscate their stock.

We shall not ask whether or not the theological expressions found in many of the hymns and songs which were disseminated in support of the "spiritualist" theology of the Silesian courtier, Caspar von Schwenckfeld, were acceptable to censors of religious ideas. Our primary focus will be on the manner in which hymns and spiritual songs by his adherents, written roughly between 1545 and 1600, treated some of his theological tenets. We shall examine the content of some of these hymns in order to understand how they developed certain theological ideas and why they illustrate some of Schwenckfeld's notions while ignoring others, which may have been of equal theological value.

One would certainly not expect, in the hymns, comprehensive coverage of Schwenckfeld's ideas. After all, he wrote more than twelve hundred tracts and treatises (often in the form of Epistolars). Many of these were reissued more than once, with some enjoying circulation beyond the boundaries of German-speaking territories. By contrast, there are a few hundred hymns at best, written by close associates such as Sudermann as well as by followers who knew Schwenckfeld's work only second hand.

Our initial investigation shows that an analysis of key theological tenets in Schwenckfelder hymns must needs be more tentative than one would like it to be. One reason for this may be, in part at least, the "underground" nature of much that was written by "unwanted" minorities and distributed among adherents or to potential converts. A second reason is undoubtedly the diffuseness of much that Schwenckfeld himself wrote. Without clear systematizing at the core of a set of accepted doctrines, one can hardly expect clarity or consistency from the popularizers of the movement who translate theologoumena into the language of popular devotion. A third and final reason for the tentativeness of our observations is the absence in the Schwenckfelder movement (not organised as a separate Protestant denomination until the early 18 th century) of a recognised magisterium. In a movement that recognizes the Holy Spirit as the ultimate transmitter of divine truth and rejects human agents as unreliable guides, transmission of the essentials of the faith cannot be easily monitored. This last factor is all too apparent in the case of the followers of Caspar von Schwenckfeld. We must therefore be content with exploring, in a concrete way, a limited body of hymns and noting some of their salient features.

Schwenckfeld had become convinced, as early as 1519 perhaps, of the need of reforming the church along the lines suggested by Martin Luther. He fondly referred to this "conversion" experience as a "gracious visitation". While he continued in the employment of three Silesian princes Karl Muensterberg-Oels, Georg Brieg and Friedrich von Liegnitz - 
he used his diplomatic skills and his considerable influence as landlord of Ossig to advance Luther's cause. When he later radicalized Luther's evangelical position he found himself increasingly in a conflict of interest situation. Rather than compromise with respect to his newly discovered principles and the insight that a true disciple of the Christ must be "poor", willing to "bear the cross" and living in total surrender [Gelassenheit] to divine will, he accepted voluntary exile in 1529 . To reduce somewhat the tension in his life between the inner being - which alone can truly be regenerated by the spirit of God - and the external being who needs external signs of God's grace such as the sacraments, Schwenckfeld chose to abstain from any celebration of the Eucharist. From 1526 onwards he never again celebrated the "external" Eucharist. Luther's call for the necessary reform of the Church in "head and members" had thus been transformed in Schwenckfeld's thought into a call for inner surrender by every individual to the will of the divine, and this commitment was no longer subject to any external norm or control. A first significant step in the direction of what is often called Protestant individualism had thus been taken. Luther's call to reform was here narrowly applied to every individual's need for regeneration. The notion of a corpus christianum, a visible communio sanctorum, as it were, had been changed into an ideal of personal holiness which would be nurtured in conventicles that needed on the part of individual participants little more than openness to the inner work of the spirit. Schwenckfeld would act, whenever possible, as a spiritual director of such groups - another reason, no doubt, why this restless seeker was never again to settle down in any socio-political community for more than a few weeks or months [an extended stay in Strasbourg from 1529 to 1533 seems to have been the exception].

For similar reasons, Schwenckfeld also played down the significance of baptism by water for infants or believers. He feared that continued use of this sacrament would merely contribute to its widespread abuse and hinder the true believer's "inner" participation in and advancement to full union with the divine. He internalized the believer's "ingrafting" and participation in the divine nature as well as communion with other believers to the point of setting aside the external symbols of baptismal water and the bread and wine of the eucharistic celebration. According to him, the Church encompasses all those who have been regenerated and made new persons by participation in the "new Adam" who is Jesus Christ. Born rather than created of God, this new Adam was not subjected to the Fall and is thus capable of restoring all who through him are made new, as if by "adoption". Any member of the race of the first Adam is a potential candidate for rebirth by the power of the inner working of the spirit of God. Since, in the eyes of Schwenckfeld and his followers, God works directly through the agency of the Spirit, any external means of grace, including the 


\section{2 / Renaissance and Reformation}

mediatorship of priests or sacramental institutions, have become largely superfluous. Any form of institutionalization of the divine was feared as an enslavement of the free power of God within mankind. For these reasons Schwenckfeld does not generally locate the Church in any visible community or in any given time and place.

In response to the uncertainties of his age which he, like many of his contemporaries, perceived as signs of "this last evil time", Sch wenckfeld chose to be a wandering prophet who would interpret the external words of Scripture (applicable to the human condition in its natural state), so that by God's "gracious visitations" these words might aid in the opening of the ear of faith and in the process of rebirth of the believer's heart. For thirtytwo years until 1561, the year of his death, Schwenkfeld pursued his calling as a student in the "school of Christ" and as the eirenic advocate of "Gelassenheit" and true regeneration.

Those who responded positively to what he taught hosted him on his constant travels, enabled him to write his numerous circular letters on all and sundry matters of spiritual counsel and theological teaching and helped disseminate his ideas through the publication of his tracts.

There was no formally structured Schwenckfelder faith community until around 1732-34 when a few hundred people who adhered to the principal tenets of Schwenckfeld organized in Pennsylvania the Schwenkfelder Church of America. It is possible, nonetheless, to identify in Europe, in the second half of the 16th century, individuals who accepted his teaching as a sound expression of evangelical faith for their own troubled times and as a valid translation of the essentials of the faith and practice of the early Christians.

From among these adherents of the Silesian nobleman three persons in particular deserve our attention as writers or publishers of hymns. These are Adam Reisner of Mindelheim (1496-1577?), Raimund Weckher (1540-1570) and Daniel Sudermann (1550-1631). The hymns of two or three others will also be mentioned. Little is known of any of the above other than that they identified with Schwenckfelder ideas. Their extant hymns cannot be dated with any precision, though Philip Wackernagel, an important collector of German hymns, has established a publication date for the broadsheet or book in which a given hymn is first found. For the time being this will have to suffice as "time of origin", though it is fairly certain that some of the hymns had existed in some form much earlier, as "transcreations" of well-known religious verse, rewritten to accommodate uniquely Schwenckfelder notions. The reverse is also true, whereby some of the Schwenckfelder hymns were modified to fit into other hymn collections after being clearly "purged" of their heretical content.

Adam Reisner [Reissner, Reusner], a one-time student of the humanist scholar Reuchlin, is one of the more prolific hymn writers. Wackernagel 
has preserved twenty-five hymns generally credited to him. Since he apparently was familiar with both Hebrew and Greek, he used this knowledge in his hymns. Many of the images characteristic of his hymns are from both the Old and New Testaments. Four of his best are metrical psalms, one of which - an adaptation of Psalm 31.1-5 - appeared under the title In te domine speravi and must be counted among the best psalm versions of the sixteenth century. The hymn appeared in the 1533 edition of Form und Ordnung Geystlicher Gesang und Psalmen in Augsburg, a few years prior to the time when its author is identified with some certainty as an exponent of the teaching of Schwenckfeld. ${ }^{1}$ The first six stanzas of this relatively short hymn are a metric version of the first five verses of the Psalm. Stanza seven is an ascription of praise addressed to the Trinity through Jesus Christ. Nothing in this hymn would suggest a specifically Schwenckfelder theology. It could have been used by any Christian as a prayer for strength and protection against the wiles of the supplicant's enemies and the deceitful world. Not surprisingly therefore, the hymn is found in many hymn books since 1533. Three other Reisner hymns are psalm adaptations [Psalms 45, 104, 130]. ${ }^{2}$ Of these, the metric arrangement of Psalm 45 is extant in two versions: one is found in Johan Zwick's Gesangbuch of 1540 and the other, in slightly different language, in the Strassburger Gesangbuch of 1568. In the latter arrangement a doxology (not in the original Psalm), appears after stanza 12. Specifically Schwenckfelder tenets such as the "spiritualized" allusion to the lordship of Jesus Christ, the bridegroom of the soul, have been edited out. Thus, Reisner's original has:

Ein feder sol die Zunge mein seines hailigen gaistes sein.

The edited version neutralized this line as follows:

Deshalben sol die Zunge mein eins schnellen schreibers feder sein.

Yet another example: the original has,

Das schwert des gaists in deiner seit

gar hoerlich sigest.

By contrast, the edited version exhorts thus:

Dein schwert an deine Seiten guert, o starker held ... 


\section{4 / Renaissance and Reformation}

Similar adjustments have been made throughout the hymn, with the later version editing out references to the work of the Holy Spirit which might have appeared too spiritualistic for the editors at a time when such radical notions were more than suspect.

Other Reisner hymns draw on different Scriptural passages, not always particular to the theology of Schwenckfeld, but representative, nonetheless, of notions that were circulated in the conventicles of brothers and sisters who adhered to his ideas.

In at least seven of these hymns the rather vivid imagery of the Book of Revelation is employed. One of the hymns extolls the celestial city, the heavenly Jerusalem, in six stanzas. The opening letters of each stanza form the acrostic JHESUS. ${ }^{3}$ Another notes the devastating rule of the Antichrist and his power, warning Christians to beware of the snares that might entrap them and tear them away from the influence of Christ the true liberator. Particularly noteworthy in this hymn is the assertion that the Christian Church ceased existing at the time of the Apostles, and the threat of death and destruction upon Christians who are such in name only, since they refuse to bear the cross of Christ. ${ }^{4}$

In nine other hymns, events or images from the gospels are prominent. Scattered throughout Reisner's hymns are also found allusions to texts from other Biblical passages such as I Corinthians 15 (death and resurrection), Romans, Acts, Genesis, Exodus and Daniel. The interpretation of these passages reflects notions that circulated in Schwenckfeld's circles. The indwelling Christ, the comfort and support he provides to those who have accepted bearing the cross as a hallmark of the true Christian [cf. Wackernagel III.191] are but two of the most prominent motifs. While one might expect mostly subjective, not to say "existential" expressions of faith, Reisner includes a few hymns that focus on the divine act of creation and liberation in a strikingly objective fashion. ${ }^{5}$

Although Daniel Sudermann played a rather important role in preserving and transmitting Schwenckfelder tenets during the second half of the sixteenth century, little has been done to provide a detailed study of the man and his work.

There appear to have been at least twelve Sudermann publications of hymns and spiritual songs, some of them in several printings. The earliest of these dates from 1572 and was published in Cologne. ${ }^{6}$ Some two hundred and ten hymns are credited to Sudermann, though for many of these he may simply have been the transmitter. Even a cursory examination of his hymns shows him to have been a far more sophisticated hymn writer than most of the other Schwenckfelders. His lyrics reflect some independance of spirit and rarely follow Scriptural texts too literally. However, one can hardly think of a more convincing voice when it came to echoing the tenets of Schwenckfeld's theology. 
As might be expected, many of Sudermann's hymns are somewhat subjective. This is particularly apparent in hymns that speak of the restoration of the soul, in confessions of guilt and in hymns that seek comfort during the wearisome struggle between God's chosen people and the enemies of Christ. One detects a note of surrender that borders on Stoic fatalism: ${ }^{7}$ should it be the will of Christ at the end of a believer's life to extend it by a measure, he would accept such "gift" gladly. On the other hand, should there be "no extension granted", the believer would accept that, too, and die happily.

This apparent "fatalism" is the hymn writer's attempt to depict the form which true "Gelassenheit" might take. The notion was clearly one of Schwenckfeld's; it was also prominent in the writings of the medieval mystics who espoused it as the ultimate attitude to adopt before mystical union with the divine is attainable. The total surrender alluded to is a by-product of yet another notion, widely held by sixteenth century radicals, namely, that the suffering of Christ calls for ready acceptance of all forms of suffering by those who aspired to be his true disciples. This principle of imitatio Christi elevated human misery to the most Christ-like mark a Christian could possibly display during his or her earthly pilgrimage. Schwenckfeld generally described it as "being disciplined in the school of Christ". Thomas Muentzer and other radicals of the day referred to it as experiencing the "bitter Christ". Under the pressure of real or imagined persecution from authorities and populace alike the only recourse for the afflicted victim was to find solace in a God whose suffering Son offered release from such affliction in his own empathic suffering.

When viewed in this light, songs of apparent despair, even gloom ring true with a note of hope and a vision of liberation. One such expression is a Sudermann acrostic, patterned after a Meistergesang:

\footnotetext{
Nun bistu ja mein Gott und Herr

auch Vatter noch, jch dein kind mehr

dein eygen, werds auch bleiben

In Ewigkeit: diss ist allein

auss grosser gnad und liebe dein.

so jch dir muss zuschreiben. ${ }^{8}$
}

There are hymns, on the other hand, which reflect the conviction that the evil world has betrayed the seeking soul. The appropriate response is renunciation of the world. In a poem of 1584 set to the tune of the French carol Chantons Noel pour la vierge honoree, Sudermann expresses this sentiment:

O blinde Welt, wie hast du mich verfuerett von jugend an biss ietz und noch zur zeitt! 
$\mathrm{O}$ arge welt. wie hast du mich bethoeret und abgebracht von rechter ban so weitt!

$O$ falsche welt.

wollust und gelt.

wee dem, der alhie auff dich helt!

Realizing the sweet charm with which the world has held the believer spell-bound, but also aware of the bitter consequences, the poet tears himself free in characteristic renunciation:

Far hin, o welt! dir will ich urlaub geben,

Far hin, o welt! ess muss gescheiden sein. ${ }^{9}$

There are other themes, of course. One of the most common is that of Christian knighthood. The knight who is valiant in war and gentle in peace toward the weak and oppressed served well as a model of the Chris. tian in combat with the forces of evil. The realism of some of these songs is remarkable. A short hymn of this genre is $A$ Song of Comfort on Christian Warfare. ${ }^{10}$ The faithful Christian warrior is challenged to endure against the forces of Satan, for in the end there will not only be victory but also "the crown of life".

Other songs in this category admit of possible defeat, but assure that ultimate victory comes for anyone who relies on Christ and who takes some initiative, even as he counts on divine grace. ${ }^{11}$ Related images are found in hymns or spiritual songs that speak of nobility of heart, perfection in the life of the spirit and ultimate victory through Christ and his power. ${ }^{12}$

Some of Sudermann's hymns use language that borders on the erotic. suggesting an intimacy between the believing soul and Christ the bridegroom that can be described as "Jesus mysticism". Their imagery is reminiscent of The Song of Solomon and of notions that may well have been drawn from medieval mystics such as Eckhart, Bonaventure and John Tauler. The husband-bride metaphors used are not infrequent, of course, in both Jewish and Christian literature. ${ }^{13}$

Other hymns of typical Schwenckfelder ring speak of the two natures of humankind (inner or spiritual and external or "of the flesh"), describe the school of Christ which imposes on the believer the harsh discipline of suffering, and wax eloquent on true humility, submission to the divine will and willing acceptance of suffering. ${ }^{14}$ Yet others describe the plight of the loving soul who yearns for her husband. ${ }^{15}$

Some hymns have distinct christological motifs in which either the glorified Christ or some aspect of his redemptive work are highlighted. ${ }^{16}$ Sudermann uses a Song of the Morning to proclaim that Jesus Christ is the only true light able to dispel error and darkness [Wackernagel V.842 - dated Feb. 1589]. 
Hymns that speak of spiritual nourishment and of the Lord's Supper as inner communion with the living God are undoubtedly the most "Schwenckfeldian" in nature. ${ }^{17}$ Such inner spiritual communion is one of the radical theologian's most distinct contributions to the debate on the nature of the sacrament of bread and wine and of Christ's presence in the Eucharist. He stressed a "spiritual" table and the internal "eating" of the "celestial Christ", and rejected any external presence and the teaching that bread and wine would somehow be transformed into the "body and blood of Christ". His followers seem to have included this belief into their hymns.

Another group of spiritual songs, to the best of my knowledge not found among other radical hymn writers of the time, is directed against "external" ceremonial Christianity. Most explicit on this point is a Sudermann hymn of 1607 in which the poet refers to the significance of having true baptism and Eucharist rather than their respective external forms, alluding, in passing, to the fact of persecution on earth "vom Sathan, auch vom Antichrist" [Wackernagel V.897, stanza 4]. ${ }^{18}$

Some hymns are obviously outside the scope of songs of meditation and inspiration and could hardly have been used in corporate worship. They contain anywhere from twenty-five to sixty-four stanzas and seem to elaborate on all possible Schwenckfeldian concepts: there is christology and soteriology, the teaching of regeneration in Christ and a forthright denunciation of external Christian worship as idolatry. Raimund Weckher is cited as the author of a Schoen new lied von der gottheyt und herrligkeyt unsers herrn Jesu Christi nach seiner edlen menschheit". ${ }^{19}$ His hymn of sixtythree stanzas is set to the tune, Ich stund an eynem morgen.

Sudermann's simple thematic songs are refreshing by comparison with others and clearly show him to be the superior poet, and a sensitive transmitter of important theological insights. Regier mich Herrnach deinem willen ${ }^{20}$ or Gottes gefuegen ist mein genuegen ${ }^{21}$ are profound expressions of faith utilizing to the utmost the song writer's skill in the use of poetic devices such as alliteration or end rhymes. In the last-named hymn each stanza begins with one word of the chosen theme:

1.Gotts hilff und gnad

mich allzeit hatt errett...

2.Gefuegen wirt

der trewe hirt....

3.Ist es wohl war ...

4.Mein hertz und gmuet... 


\section{Genuegen soll}

mir hertzlich woll...

One last type of spiritual song which deserves mention, though it is less suited to corporate worship than it is to "confidence building", is a curious mix of a Schwenckfeldian regula fidei, and open attack on religious opponents. This apologia pro vita sua is used with some success by Raimund Weckher (c. 1540-1570) and Alexander Berner (c. 1550).

There may have been others, of course, since this form of spreading one's own beliefs while ridiculing others was not uncommon. ${ }^{22}$ When set to popular tunes, such colourful - if unholy - ranting enabled hymn writers to send subliminal messages or to berate an unwelcome ideological position. The memorability and effective dissemination of such verbal barbs were enhanced by the use of folk tunes, whose familiarity could be assumed. Two examples will suffice.

In a song of sixteen stanzas of five lines each, Alexander Berner describes Four sects and repugnant churches of his day. He has the Pope, Luther, Zwingli and the Anabaptists in turn praise their respective peculiarities of doctrine. The unregenerate observer, naturally turns away in disgust. ${ }^{23}$

Der Weltmensch spricht, “Was kuemmerts mich

das die glerten ietz spalten sich?

bey keiner sect sich bessrung ich:

Ich will beim hauffen bleiben,

sonst moecht man mich vertreiben."

However, when Christ takes over, all divisions fall by the way. None of the four has a case. ${ }^{24}$

Christus der spricht, "Secht all auff mich, auff Menschen keinr verlasse sich, den rechten weg muss lehren ich, Mein Geist kan ich mittheilen, kein Mittel wuerdt euch heilen."

[stanza 15]

Another song of this nature is by one Esaias Tribauer. It appeared in 1571 as, Ein gesang wider die Teuflische und verfuerische Sect der Schwenckfelder. Like Four Sects it is set to a popular tune to ensure widespread circulation. The tone of the sarcasm is rather harsh. Playing on the syllable schwenck (swing, alternate, hence be unreliable) the song begins thus:

Ihr Schwenckfeldischen Schwencker, schwencket euch her zu mir.

Ihr seid doch rechte Stencker. 
stinket wohl fuer und fuer,

Hoert was ich sagen will:

Gott wird es euch nit schencken

wirdt euch zur hellen Schwencken

wern ewer noch so viel. ${ }^{25}$

[Wackernagel V. 792, stanza 1]

Even as the writer details the false teachings of his opponents he is not above invoking the Holy Spirit, whose guidance he vows to heed as he obeys the preached word and honours the sacraments [an obvious allusion to Luther's emphasis on the external proclamation of the word through sermons and participation by the believer in the external means of grace, that is, water, bread and wine].

The author appeals to public support, counting on the fact that theologically unsophisticated believers would prefer the certainty of visible manifestations of "holy things" to the internalized expressions of Schwenckfeldian theology. We may find the crude manner of denouncing minorities. rather offensive. At the time, however, broadsheets which contained such rants seem to have been widely circulated, though it is not yet clear on what occasions - if ever - such rants were actually sung.

In conclusion, two points should be stressed. Most Schwenckfelder hymn writers were obviously not primarily poets. Their hymns and spiritual songs were rather mundane efforts to condense in simple, memorable rhymes some of the theological tenets their spiritual "leader" had passed on to them in his more than twelve hundred tracts and letters.

Nonetheless, in their songs they sought to glorify God and communicate to one another the mystery of his redemptive work in the human soul, among the race "that long in darkness lay". One such hymn, generally ascribed to Reisner, embodies both their vision and their style in a conclusive manner:

Christ erstanden

macht sein feind zu schanden,

Hatt uberwunden, dseligkaytt uns funden, Unnd uns das leben durch sein todt gegeben. Christus der Herre, kuenig der Ehren.

Diser welt kinder bleyben ymmer suender, Christum verachten, ihn zu dempfen trachten:
Seyn fleysch empfangen und am Creutz gehangen

Hatt er ausgefueret, mit Gotthaytt gezieret, Ins Reych gesetzet, alles layds ergoetzet:

Christus is Herre, kuenig der Ehren.

Das Christus kuening gefelt der welt gar wenig:

Er ist gepreyset,

Gottes Son erweyset: 
Wirt doch Gott bleyben unnd sie undertreyben, Christus der Herre kuenig der Ehren.
Die jr vor sunder jetzt seid Gottes kinder, Lobt disen Herren kuenig der Ehren. ${ }^{26}$

\section{McGill University}

\section{Notes}

1 Cf. The Handbook to the Lutheran Hymnal (St. Louis: Concordia Publishing House, 1942), p. 369. For Schwenckfeld's teaching cf. Chester D. Hartranft, et. al., ed.s, Corpus Schwenckfeldianorum (Leipzig \& Pennsburg, Pa.: The Board of Publication of the Schwenckfelder Church, 1907-36, 1959-61).

Although we have no reliable date for Reisner's conversion to Schwenckfeld's school of thought, E. Johnson in a thesis draft submitted to the Hartford Seminary ("Adam Reisner of Mindelheim - Diplomat, Linguist, Historian and Poet") suggests that he served as the nobleman's amanuensis after 1548 .

2 Cf. P. Wackernagel, Das deutsche Kirchenlied, 5 volumes (Leipzig: Teubner Verlag, 1864-77); hence referred to as Wackernagel I-V with reference to hymn numbers. See especially, 111.170 (Ps. 31), 111.177 (Ps. 45), 111.178 (Ps. 104), 111.181 (Ps. 130) and 111.188 (Ps. 72 ).

3 Wackernagel 111.179.

4 Ibid., 111.190. The restitutionist theory here advanced is found among sixteenth century radicals other than Schwenckfelders. It holds that the Church has not really been apparent in the medieval structures but has subsisted "invisibly" as an underground reality sustained only by the Spirit of God.

5 Cf. especially Wackernagel 111. 172, 174, 182, 193. However, an occasional reference to the self appears even in these hymns.

6 Wackernagel V.546f lists a dozen Sudermann publications, the earliest of which seems to have t ven 1572.

7 Ibid., V. 836, 837.

8 Ibid., V.p. 846. The acrostic is from 1580 on the poet's name: Daniel Suderman. We have quoted the last stanza [translations throughout this paper, unless otherwise indicated, are mine].

9

O blind world, how you have goaded me

from early youth till now.

O evil world, how you enchanted me

and led me off the way.

$\mathrm{O}$ false world,

riches and lust

woe unto him who in you trusts.

pass on, o world, I give you leave pass on, o world, we now must part [Cf. V. $815(1584)$ ]

Similar sentiments may be found in V. 873 and in other hymns that contrast the state of the new being in Christ with the sinful, natural state of creation.

10 Cf. Wackernagel V. 908. The title reads, Ein trostlied vom Christlichen Streit. The Christian warrior is urged to fight valiantly against Satan and the flesh since his human abode is merely one of the battle grounds of the "spiritual warfare". In such knowledge lies the warrior's comfort.

11 Ibid., 940, On Christian Warfare

How many a Christian knight

falls wounded in the fight with sin, 
oft nearing death

when God gives him new breath.

Just let him boldly stand,

fight on and not relent.

Fight on more bravely

than before.

Then victory is sure -

as long as wars endure,

which is throughout all life -

with Christ's singular help.

12 Hymns describing Christian knighthood and warfare are found in Wackernagel V. 877, $908,999$.

13 Cf. Ibid., V. $886,888,889,950-65$. Stress is laid on Christian purity and on the inner union with Christ, more profitable than any form of external learning.

14 For additional material, cf. Wackernagel, V. 779, 780, 782, 846, 925, 926, 882, 891-93.

15 Cf. Ibid., 949, 950, 952, 961, 974, 983, 984, 986, 988-90.

16 Christological motifs may be found in Vom Reich und Gericht Christi (111.192) and in Ein Lied vom glorificierten Christo (111.184). See also V. 773, 842, 861.

17 Cf. Wackernagel V. $777,778,935,941$. Held's are the more explicit in this genre.

18 Relevant numbers are Wackernagel V. 776, 790, 792, 894, 897.

19 The author is Raimund Weckher (Wackernagel V. 773). By the same author is a polemic against Coccius (Ibid., 774). Playing on the similarity of sound the author likens Coccio to a cuckoo who places her eggs in the nest of other birds - in other words, Coccius is a parasite.

20 Wackernagel, V. 824.

21 Ibid., 821.

22 Ibid., 790, stanza 12.

The unregenerate man says, "What do I care

that all the scholars are divided?

There is no change in any sect,

So I'll remain with the crowd,

lest they exile me."

Cf. Sebastian Franck's Von vier zwietraechtigen Kirchen for a similar motif. The song is reprinted in Heinold Fast, Der linke Fluegel der Reformation (Bremen: Carl Schünemann Verlag, 1962), $246 \mathrm{ff}$.

23 In a paper currently in preparation, I explore the use of such rants in Lutheran, Reformed and Roman Catholic circles in the second half of the sixteenth century.

Christ says, "Look upon me,

No one on humans can rely.

I must show you the right way,

I must transmit my spirit,

No substitute can heal you."

You Schwenckfeldian swingers [turncoats?]

Swing over to hear me.

You are indeed real stinkers,

Stinking eternally,

Hear what I'm about to sing:

God will not let you by: 


\section{2 / Renaissance and Reformation}

To hell he'll send you by and by

Even though there be many of you.

26 Wackernagel 111.184. We have translated the first four stanzas only. The fifth stanza introduces an eschatological dimension that would take us into yet another theological tenet advanced by many 16th century "radicals".

The risen Christ

confounds all his foes.

He has conquered, brought salvation to us

in giving life eternal

by his cruel death.

Christ the Lord,

king of all glory.

Assuming human flesh

hanging on the cross

he accomplished all,

With divinity adorned

he placed us in his kingdom

freed from all woe,

Christ the Lord

king of all glory

This world's children

That Christ is king

are forever sinners

they despise Christ,

seek to keep him human.

Yet he remains God

the world pleases little.

$\mathrm{He}$ is most blessed

reveals his divine sonship.

and will thus confound them.

Once you were sinners,

Christ the Lord,

king of all glory.

Now you are God's children.

Praise ye the Lord,

king of all glory. 